\title{
Autophagy and Mitophagy
}

\author{
Kao Li-Pin ${ }^{1,2 *}$ \\ ${ }^{1}$ Department of Medicine, Mayo Clinic, Scottsdale, USA \\ ${ }^{2}$ Australian Institute for Bioengineering and Nanotechnology, The University of Queensland, Australia
}

Submission: August 04, 2017; Published: August 11, 2017

*Corresponding author: Kao Li-Pin, Department of Medicine, Mayo Clinic, Scottsdale, Arizona, 13400 East Shea Boulevard, Scottsdale, Arizona 85259, USA, Australian Institute for Bioengineering and Nanotechnology, The University of Queensland, Australia, Email: kaolp@yahoo.com.tw

\begin{abstract}
Mitochondria are cellular organelles that are critical for energy production. They also serve as signalling hubs, integrating a variety of inputs related to metabolic demand, redox control, and apoptosis. The mass and quality of mitochondria within a cell are determined by a balance between mitochondrial biogenesis and mitochondrial turnover. It is important to understand how autophagy and mitophagy can specific play a role in the cell therapy field. A more thorough understanding of the molecular mechanisms controlling mitophagy in a homeostasis may eventually allow for manipulation of this process, a technology that could improve the mitochondrial quality in cell therapy and thus facilitate the therapeutic application of these cells in regenerative medicine.
\end{abstract}

Keywords: Autophagy; Mitophagy

\section{Autophagy}

Autophagy is derived from the Greek words auto, which means "self", and phagy, which means "to eat." The autophagic process breaks down cellular components and plays a particularly important role during periods of starvation, or when organelles are damaged [1]. This allows cells to balance synthesis, degradation, and recycling of cellular structures. Autophagosomes are double-membrane cytosolic vesicles that encapsulate superfluous or damaged cellular components and break them down to either supply nutrients to the cell or finetune organelle content [2-4]. Not surprisingly, then, during development autophagy plays a significant role in cell growth, and in homeostasis.

The process of autophagy occurs in four discrete steps:

i. Induction,

ii. Formation of an autophagosome,

iii. Fusion of the autophagosome with lysosomes, and

iv. Breakdown of sequestered components (following fusion with lysosomes) into metabolic products that are subsequently released into the cytoplasm [5].

Autophagy is believed to be essential for healthy aging and longevity, and the target of rapamycin (TOR) pathway, which is a key regulator of autophagy, is one of three highly conserved signaling pathways that affect cellular lifespan $[4,6]$.
Conversely, deregulated autophagy has been linked to both neurodegeneration and cancer.

\section{Mitophagy}

Mitophagy is a specific form of autophagy that degrades damaged mitochondria [2]. Mitophagy can occur under nutrientrich conditions, such as the maturation of erythrocytes during development, or under nutrient-poor conditions following damage of mitochondria $[2,7,8]$. In the latter case, damaged mitochondria are selectively eliminated to maintain optimal mitochondrial function and thereby cellular integrity [9-12]. In doing so, mitophagy serves as an important mechanism of quality control for the mitochondrial population within the cell. The mitochondrion is the major site of oxygen consumption and ATP production, and is an integral part of the apoptotic machinery. Mitochondria generate reactive oxygen species (ROS) as a by-product of oxidative phosphorylation. Damaged mitochondria often produce large amounts of ROS and exhibit a drop in mitochondrial membrane potential. These mitochondria subsequently present "eat-me" signals (e.g., PARKIN and PINK1), which trigger autophagosomal engulfment and mitophagy $[13,14]$. Mitophagy occurs by Parkin being selectively recruited from the cytosol to promote the destruction of dysfunctional mitochondria [10] and this is initiated by mitochondrial membrane depolarization [15-17]. Specifically, Parkin recruitment occurs through ubiquitination of the voltage- 
dependent anion channel 1 (VDAC1, an outer mitochondrial membrane protein) which next recruits p62 (an autophagy receptor) to the damaged mitochondrion $[15,18]$, and promote interaction with LC3 on the surface of phagophores. This ultimately leads to engulfment by autophagosomal structures followed by lysosomal degradation (i.e. mitophagy). As such, mitochondria can be degraded through autophagy and can often be detected within autophagosomes [4].

\section{Disclosure of potential conflicts of interest}

The author indicates no potential conflict of interest.

\section{Acknowledgment}

The authors would like to acknowledge the financial support of the Australian Postgraduate Award and the support of the Australian Stem Cell Centre's Core hESC Laboratories (Stem Core) for providing cell culture and support services and Mayo Clinic provided support in the form of salaries for KLP listed, but did not have any additional role in the study design, data collection and analysis, decision to publish, or preparation of the manuscript.

\section{References}

1. Ding WX, Yin XM (2012) Mitophagy: mechanisms, pathophysiological roles, and analysis. Biol Chem 393(7): 547-564.

2. Kim I, Rodriguez-Enriquez S, Lemasters JJ (2007) Selective degradation of mitochondria by mitophagy. Arch Biochem Biophys 462(2): 245253.

3. Vives-Bauza C, Przedborski S (2011) Mitophagy: the latest problem for Parkinson's disease. Trends Mol Med 17(3): 158-165.

4. Yen WL, Klionsky DJ (2008) How to live long and prosper: autophagy, mitochondria, and aging. Physiology (Bethesda)23: 248-262.

5. Kundu M, Thompson CB (2008) Autophagy: basic principles and relevance to disease. Annu Rev Pathol 3: 427-455.
6. Eisenberg T, Heide K, Alexandra S, Sabrina B, Christoph R, et al. (2009) Induction of autophagy by spermidine promotes longevity. Nat Cell Biol 11(11): 1305-1314.

7. Kanki T, Klionsky DJ (2010) The molecular mechanism of mitochondria autophagy in yeast. Mol Microbiol 75(4): 795-800.

8. Tolkovsky AM (2009) Mitophagy. Biochimica et biophysica acta 1793(9): 1508-1515.

9. Elmore SP, Qian T, Grissom SF, Lemasters JJ, et al. (2001) The mitochondrial permeability transition initiates autophagy in rat hepatocytes. Faseb J 15(12): 2286-2287.

10. Narendra D, Tanaka A, Suen DF, Youle RJ, et al. (2008) Parkin is recruited selectively to impaired mitochondria and promotes their autophagy. J Cell Biol 183(5): 795-803.

11. Priault M, Salin B, Schaeffer J, Vallette FM, di Rago JP, et al. (2005) Impairing the bioenergetic status and the biogenesis of mitochondria triggers mitophagy in yeast. Cell Death Differ 12(12): 1613-1621.

12. Rodriguez-Enriquez S, Kim I, Currin RT, Lemasters JJ (2006) Tracker dyes to probe mitochondrial autophagy (mitophagy) in rat hepatocytes. Autophagy 2(1): 39-46.

13. Sandoval H, Thiagarajan P, Dasgupta SK, Schumacher A, Prchal JT, et al. (2008) Essential role for Nix in autophagic maturation of erythroid cells. Nature 454(7201): 232-235.

14. Vives-Bauza C, Zhou C, Huang Y, Cui M, de Vries RL, et al. (2010) PINK1dependent recruitment of Parkin to mitochondria in mitophagy. Proc Natl Acad Sci U S A 107(1): 378-383.

15. Geisler S, Holmström KM, Skujat D, Fiesel FC, Rothfuss OC, et al. (2010) PINK1/Parkin-mediated mitophagy is dependent on VDAC1 and p62/ SQSTM1. Nat Cell Biol 12(2): 119-131.

16. Narendra DP, Jin SM, Tanaka A, Suen DF, Gautier CA, et al. (2010) PINK1 is selectively stabilized on impaired mitochondria to activate Parkin. PLoS biology 8(1): e1000298.

17. Park J, Lee G, Chung J (2009) The PINK1-Parkin pathway is involved in the regulation of mitochondrial remodeling process. Biochem Biophys Res Commun 378(3): 518-523.

18. Wild P, Dikic I (2010) Mitochondria get a Parkin' ticket. Nat Cell Biol 12(2): 104-106.

\begin{tabular}{|l|}
\hline Your next submission with Juniper Publishers \\
will reach you the below assets \\
- Quality Editorial service \\
- Swift Peer Review \\
- Reprints availability \\
- E-prints Service \\
- Manuscript Podcast for convenient understanding \\
- Global attainment for your research \\
- Manuscript accessibility in different formats \\
( Pdf, E-pub, Full Text, Audio) \\
- Unceasing customer service \\
Track the below URL for one-step submission \\
https://juniperpublishers.com/online-submission.php
\end{tabular}

